\title{
Correlation Between Serum HCV RNA and Aminotransferase Levels in Patients with Chronic HCV Infection
}

\author{
M.G. GHANY, MD, T.M. CHAN, MD, R. SANCHEZ-PESCADOR, PhD, M. URDEA, PhD, and \\ A.S.F. LOK, MD
}

\begin{abstract}
Cross-sectional studies on the correlation between serum hepatitis $\mathrm{C}$ virus (HCV) RNA and alanine aminotransferase (ALT) levels in patients with chronic hepatitis $C$ have yielded conflicting results. We conducted a longitudinal study to examine the correlation between $\mathrm{HCV}$ viremia and serum ALT levels in individual patients over time. Serial samples (mean 9) from 25 patients with chronic $\mathrm{HCV}$ infection, including interferon-treated and untreated immunocompetent and immunosuppressed patients, collected over a period of 1-4.8 years (mean 2.6 years) were tested for HCV RNA and ALT levels using a highly reproducible quantitative (bDNA) assay. A significant correlation was found between serum HCV RNA and ALT levels in the patients who received IFN therapy, but no correlation was observed in the untreated patients. Among the untreated patients, the immunosuppressed patients had significantly higher HCV RNA levels ( $39 \pm 4$ vs $3.6 \pm 8 \mathrm{Meq} / \mathrm{ml}, P<0.0001)$ but significantly lower ALT (56 \pm 11 vs $97 \pm 12$ units/liter, $P=0.03$ ) levels when compared to the immunocompetent ones. In summary, we found no correlation between serum HCV RNA and ALT levels in chronic hepatitis C patients who are not receiving interferon therapy. Immunosuppression results in higher HCV RNA but lower ALT levels.
\end{abstract}

KEY WORDS: immunosuppressive therapy; renal transplantation; chronic hepatitis C; interferon.

The pathogenesis of hepatitis $\mathrm{C}$ virus (HCV) -induced liver injury remains unresolved. Early studies suggested that $\mathrm{HCV}$ may be a cytopathic virus. This is supported by reports that patients with more active or advanced liver disease have higher levels of viremia (1-8). In addition, among patients who receive interferon therapy, a decrease in serum aminotransferase (ALT) levels during treatment is usually accompanied by a parallel fall in serum HCV RNA

\footnotetext{
Manuscript received February 8, 1996; revised manuscript received August 1, 1996; accepted August 3, 1996.

From the Section of Gastroenterology and Hepatology, Tulane University Medical Center, New Orleans, Louisiana; Department of Medicine, University of Hong Kong, Hong Kong; and Chiron Corporation, Emeryville, California.

Address for reprint requests: Dr. Anna S.F. Lok, Division of Gastroenterology, University of Michigan Medical Center, 3912 Taubman Center, Box 0362, 1500 East Medical Center Drive, Ann Arbor, Michigan 48109.
}

levels, and a relapse in ALT levels after treatment is accompanied by reappearance of HCV RNA in serum (9-14). However, recent studies found that while immunosuppressive therapy increases serum $\mathrm{HCV}$ RNA levels, ALT levels are decreased, suggesting that $\mathrm{HCV}$-induced liver injury is immune-mediated (15-18). Other evidence in support of immunemediated liver injury in chronic hepatitis $\mathrm{C}$ is the frequent presence of lymphoid aggregates in the portal tracts which contain activated $\mathrm{B}$ as well as $\mathrm{T}$ cells $(19,20)$ and the recent demonstration of cytotoxic $T$ lymphocytes that react against $\mathrm{HCV}$ antigens in liver biopsies (21-27). Furthermore, some studies found no correlation between serum HCV RNA levels and biochemical/histological activity of liver disease $(2$, $4-7,28)$. 
GHANY ET AL

Several factors contribute to the discrepant reports on the correlation between serum HCV RNA and ALT levels. Most reports were based on crosssectional studies. It is possible that the relationship between serum HCV RNA and ALT levels may differ in different patients depending on the stage of liver disease and immune response of the host. More meaningful data may be generated by studying serial samples from the same patients. While there are many reports on the effects of interferon therapy on changes in serum ALT and HCV RNA levels, very few longitudinal studies have been performed on untreated patients $(1,28)$. Most of the latter studies employed assays [such as end-point dilution polymerase chain reaction (PCR) assay] that have marked interassay variability and are at best semiquantitative. Owing to the laborious nature of these assays, very few samples at scattered time points were tested for serum HCV RNA levels. Thus, accurate correlation between serum HCV RNA and ALT levels cannot be determined.

The aim of this study was to reexamine the correlation between the level of hepatitis $C$ viremia and activity of liver disease (as determined by ALT level) in patients with chronic $\mathrm{HCV}$ infection by testing multiple serum samples using a highly reproducible, quantitative HCV RNA assay (bDNA). To determine whether the relationship between serum HCV RNA and ALT levels is affected by antiviral and immunosuppressive therapy, three groups of patients were studied: untreated and interferon-treated immunocompetent patients and renal transplant recipients who received immunosuppressive therapy.

\section{MATERIALS AND METHODS}

Patients. Twenty-five patients (14 men and 11 women), age 23-74 years (mean \pm SEM $44 \pm 3$ years) with chronic HCV infection, who attended the Hepatitis Clinic and the Renal Transplant Clinic in Queen Mary Hospital, Hong Kong, were studied. All patients were anti-HCV positive by second-generation enzyme immunoassays (EIA-2). They included 13 immunocompetent patients and 12 renal transplant recipients. The risk factors for $\mathrm{HCV}$ infection were: transfusions in 20 (including eight who had hemodialysis), occupational exposure in one, and unknown in four (Table 1). HCV genotyping data was available in 19 patients showing genotypes $1 \mathrm{~b}$ in $14,2 \mathrm{~b}$ in one, $3 \mathrm{a}$ in one, and $6 \mathrm{a}$ in three. Eighteen patients had liver biopsies which showed: minimal changes in five, chronic persistent hepatitis in two, chronic active hepatitis in nine, and cirrhosis in two (Table 1). Among the immunocompetent patients, five received interferon- $\alpha_{2 b}$ therapy, all had elevated ALT levels and liver biopsies showing chronic hepatitis prior to initiation of treatment. Four patients received $3 \mathrm{MU}$ doses of interferon
Table 1. Characteristics of Patients at Presentation*

\begin{tabular}{|c|c|c|c|}
\hline & \multicolumn{2}{|c|}{ Intmunocompetent } & \multirow{2}{*}{$\begin{array}{l}\text { Immunosuppressed } \\
\text { renal transplant }\end{array}$} \\
\hline & Treated & Untreated & \\
\hline Patients $(N)$ & 5 & 8 & 12 \\
\hline \multicolumn{4}{|l|}{ Age (yr), mean \pm} \\
\hline SEM & $34 \pm 3$ & $55 \pm 5$ & $40 \pm 3$ \\
\hline Sex m/f & $2 / 3$ & $4 / 4$ & $8 / 4$ \\
\hline \multicolumn{4}{|l|}{ Risk factors } \\
\hline Blood transfusion & 4 & 4 & 4 \\
\hline Occupational & 1 & 0 & 0 \\
\hline Transfusion $+\mathrm{HD}$ & 0 & $\mathbf{0}$ & 8 \\
\hline \multicolumn{4}{|l|}{ Genotype } \\
\hline lb & 3 & 3 & 8 \\
\hline $2 b$ & 1 & 0 & 0 \\
\hline $3 \mathbf{a}$ & 1 & 0 & 0 \\
\hline 6 & 0 & 1 & 2 \\
\hline N/A & 0 & 4 & 2 \\
\hline \multicolumn{4}{|l|}{ Liver histology } \\
\hline Minimal change & 0 & 0 & 5 \\
\hline $\mathrm{CPH}$ & 1 & 0 & 1 \\
\hline $\mathrm{CAH}$ & 4 & 2 & 3 \\
\hline Cirrhosis & 0 & 2 & 0 \\
\hline $\mathrm{N} / \mathrm{A}$ & 0 & 4 & 3 \\
\hline
\end{tabular}

* HD, Hemodialysis; N/A, not available; CPH, chronic persistent hepatitis; $\mathrm{CAH}$, chronic active hepatitis.

thrice weekly for six months, the other patient received 3- to 5-MU doses for 12 months. Initial response was defined as normalization in ALT levels at the end of treatment and sustained response as normalization in ALT levels that was maintained for at least six months after treatment. All the renal transplant recipients were anti-HCV-positive prior to transplant, and all received triple immunosuppressive therapy: prednisone, azathioprine, and cyclosporine. All patients were negative for hepatitis B surface antigen ( $\mathrm{HBs} A \mathrm{~g}$ ) and antibody to human immunodeficiency virus (anti-HIV) and had no other causes of liver disease.

Methods. Between 1990 and 1994, an aliquot of serum was collected from all anti-HCV-positive patients at each clinic visit (every one to six months) and stored at $-70^{\circ} \mathrm{C}$ for HCV RNA and genotype assays. Serial samples, 5-13 (mean $9 \pm 0.5$ ), from each patient collected over a period of $1-4.8$ years (mean $2.6 \pm 0.2$ years) were studied. Anti-HCV was tested by EIA-2; HBsAg and anti-HIV were tested by EIA (Abbott Laboratories, North Chicago, Illinois). Serum HCV RNA was detected by a nested reverse transcriptionPCR (RT-PCR) assay as described previously (29) and quantitated by the branched-chain DNA assay (Quantiplex bDNA assay, Chiron Corp., Emeryville, California). The detection limit of the assay is $3.5 \times 10^{5}$ viral equivalents per milliliter of serum $(0.35 \mathrm{Meq} / \mathrm{ml})$. HCV genotyping was performed using a modification of the Okamoto PCRbased typing assay that can differentiate genotypes 1a, 1 , $2 \mathrm{a}, 2 \mathrm{~b}$, and $3 \mathrm{a}(30)$. Additional primers were incorporated to identify genotype $6 \mathrm{a}$, which is the second most prevalent HCV genotype in Hong Kong (31).

Statistical Analyses. An arbitrary value of $0.175 \mathrm{Meq} / \mathrm{ml}$ was assigned to serum samples that were undetectable for HCV RNA in the bDNA assay. All analyses on serum HCV RNA levels were performed using logarithmically transformed values. Pearson's test was used to analyze the cor- 


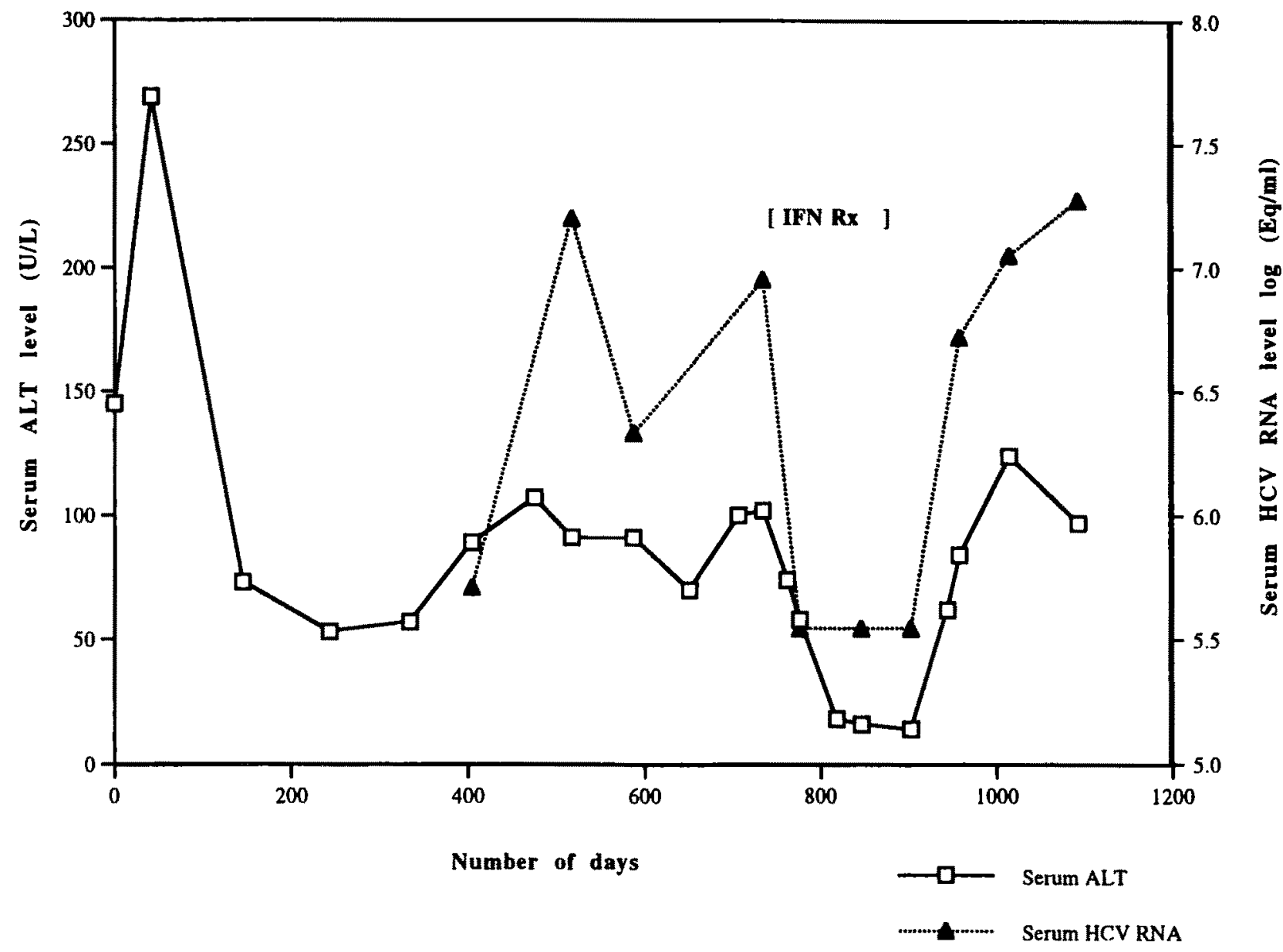

Fig 1. Parallel changes in serum ALT and HCV RNA levels in an interferon-treated patient.

relation between serum HCV RNA and ALT levels. An additional correlation coefficient was calculated for each individual patient by comparing all the paired serum $\mathrm{HCV}$ RNA and ALT levels for that patient. In the interferon treated patients, a separate correlation coefficient was calculated for the period from one month before treatment to one month after treatment. Variations in serum HCV RNA and ALT levels during the course of follow-up were calculated by determining the ratio of the peak versus trough HCV RNA and ALT levels for each individual patient. Comparisons between groups were performed using the Mann-Whitney test.

\section{RESULTS}

Interferon-Treated Patients $(N=5)$. All five patients were HCV RNA-positive by RT-PCR, and four (80\%) had detectable HCV RNA by the bDNA assay prior to treatment. Initial and sustained response was achieved in four and one patients, respectively. Parallel changes in serum HCV RNA and ALT levels were observed during treatment in the four patients who had detectable HCV RNA by the bDNA assay at the onset of treatment (Figure 1). There was a significant correlation between serum HCV RNA and ALT levels, especially during the treatment period. The mean correlation coefficients and $P$ values for the entire observation period were 0.6 and 0.13 and for the treatment period were 0.91 and 0.02 , respectively. All four responders became serum HCV RNAnegative at the end of treatment, but only the sustained responder remained HCV RNA-negative during posttreatment follow-up.

Untreated Patients $(N=20)$. Of the 20 untreated patients, 12 (three immunocompetent and nine renal transplant patients) were persistently serum $\mathrm{HCV}$ RNA-positive by the bDNA assay. Serum HCV RNA was intermittently undetectable in four immunocompetent and three renal transplant patients. Serum HCV RNA was persistently undetectable by the bDNA assay in one immunocompetent patient, al- 


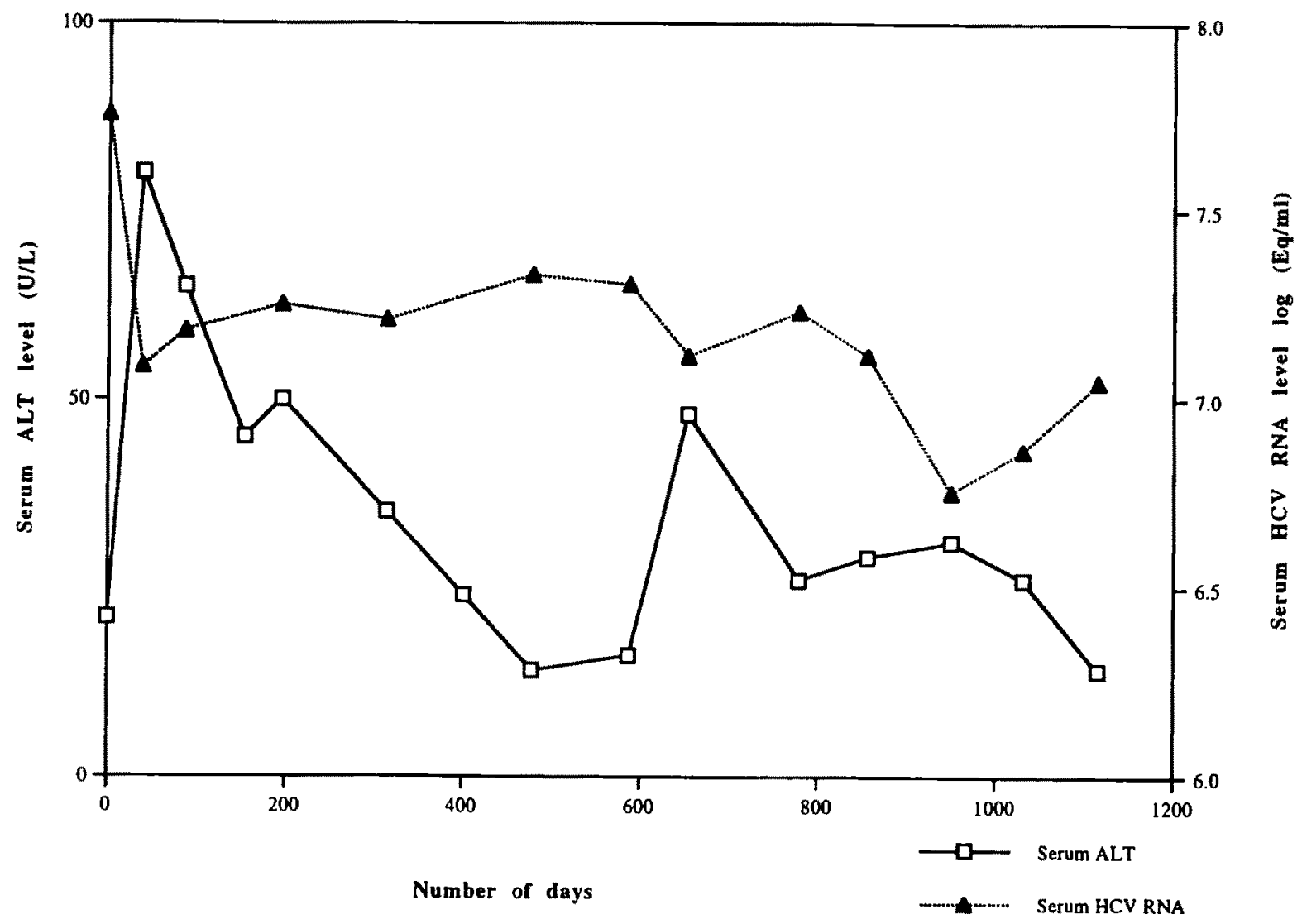

Fig 2. Lack of correlation between serum ALT and HCV RNA levels in an untreated renal transplant recipient.

though he was HCV RNA-positive by RT-PCR. No correlation between serum HCV RNA and ALT levels was observed in any of the 20 untreated patients (Figure 2). The correlation coefficients varied from 0.07 to 0.83 and the $P$ values ranged from 0.06 to 0.97 .

Compared to the immunocompetent patients, the renal transplant recipients were similar in age: $40 \pm 3$ vs $55 \pm 5$ years and had a similar prevalence of $\mathrm{HCV}$ genotype 1b: 8 of 10 vs 3 of 4 (Table 1). Despite significantly higher mean serum HCV RNA levels
$[39 \pm 4$ vs $3.6 \pm 0.8 \mathrm{Meq} / \mathrm{ml}(P<0.0001)]$, the renal transplant recipients had significantly lower mean ALT levels: $56 \pm 11$ vs $97 \pm 12$ units/liter $(P=0.03)$ (Table 2) and milder histological liver disease: five of nine had minimal changes versus none of four among immunocompetent patients (NS). The renal transplant recipients had fivefold greater variations in serum HCV RNA levels: $43 \pm 20$ vs $8 \pm 2$ but a similar degree of variation in ALT levels: $5 \pm 1$ vs $4 \pm 1$ (Table 2).

Table 2. Comparison BetweEn SERum HCV RNA and ALT LeVels in Untreated IMMUNOCOMPETENT (IC) AND RENAL TRANSPLANT (RT) PATIENTS*

\begin{tabular}{lccc}
\hline & \multicolumn{2}{c}{ Untreated patients } & \\
\cline { 2 - 3 } & Immunocompetent & Renal transplant & $\mathrm{P}$ \\
\hline Patients $(N)$ & 8 & 12 & \\
Points evaluated $(N)$ & 58 & 111 & \\
Duration of follow-up $(\mathrm{mo})$ & $22 \pm 2(13-32)$ & $39 \pm 4(21-57)$ & 0.03 \\
Mean ALT (units/liter) & $97 \pm 12(47-143)$ & $56 \pm 11(17-136)$ & 0.03 \\
Variation in ALT during follow-up & $4 \pm 1(1.5-4.8)$ & $5 \pm 1(1.5-14.4)$ & NS \\
HCV RNA Level (eq/liter $\left.\times 10^{6}\right)$ & $3.6 \pm 0.8(0.175-39.55)$ & $39 \pm 4(0.175-96)$ & $<0.0001$ \\
Variation in HCV RNA during & $8 \pm 2(1-21)$ & $43 \pm 20(2-256)$ & \\
$\quad$ & & & \\
\hline
\end{tabular}

* Values expressed as mean \pm SEM (range). 


\section{DISCUSSION}

We previously reported a lack of correlation between serum HCV RNA and ALT levels in chronic hepatitis $C$ patients in a longitudinal study (23). In that study, serum HCV RNA level was quantitated using a semiquantitative assay (end-point dilution RT-PCR assay) that had a 10-fold interassay variability. Considerable controversy exists in the published literature regarding the relationship between levels of hepatitis $\mathrm{C}$ viremia and biochemical/histological activity of liver disease in patients with chronic $\mathrm{HCV}$ infection $(2-6,23)$. This is in part related to the poor standardization and interassay variability in amplification efficiency of RT-PCR assays. In this study, multiple samples $[5-13$ (mean $9 \pm 0.5$ )], at close intervals were tested for serum HCV RNA levels using a more consistent quantitative assay that relies on amplification of enzyme signal rather than nucleic acids. We confirmed our previous finding that except during interferon treatment, there was no correlation between serum HCV RNA and ALT levels in both immunocompetent and immunosuppressed patients with chronic $\mathrm{HCV}$ infection. This suggests that $\mathrm{HCV}$ induced liver injury is not a direct result of the cytopathic effects of the virus. Further support against cytopathic liver injury is evidenced by the paradoxical increase in serum HCV RNA and decrease in ALT levels and the milder histological changes in renal transplant recipients receiving immunosuppressive therapy. In addition, while the renal transplant recipients had fivefold greater variations in serum $\mathrm{HCV}$ RNA levels compared to the untreated immunocompetent patients, the variations in ALT levels were similar.

In accordance with other investigators, we found significant (up to 14-fold) variations in ALT levels during the course of chronic HCV infection $(32,33)$. Significant variations including intermittent disappearance in serum HCV RNA levels were also observed in the untreated patients. Intermittent loss of viremia has also been reported by other investigators using more sensitive RT-PCR assays $(32,33)$. The variability in serum HCV RNA and ALT levels may reflect fluctuations in the balance between host immune response and level of HCV replication and/or emergence of new versus changes in the proportion of existing viral quasispecies.

In summary, we found that there was no correlation between serum HCV RNA and ALT levels during the natural course of chronic HCV infection. Immuno- suppression resulted in significantly higher serum HCV RNA but significantly lower ALT levels.

\section{REFERENCES}

1. Naito $M$, Hayashi $N$, Hagiwara $H$, Katayama $K$, Kasahara $A$, Fusamoto $H$, Kato $M$, Masuzawa $M$, Kamada T: Serial quantitative analysis of serum hepatitis $C$ virus RNA level in patients with acute and chronic hepatitis C. J Hepatol 20:755759, 1994

2. Hagiwara $H$, Hayashi N, Mita E, Naito $M$, Kasahara A, Fusamoto $H$, Kamada $T$ : Quantitation of hepatitis $C$ virus RNA in serum of asymptomatic blood donors and patients with type $C$ chronic liver disease. Hepatology 17:545-550, 1993

3. Kato $N$, Yokosura $O$, Hosoda $K$, Ito $Y$, Ohto Omata $M$ : Quantification of hepatitis $C$ virus by competitive reverse transcription-polymerase chain reaction: Increase of the virus in advanced liver disease. Hepatology 18:16-20, 1993

4. Gordon SC, Vallisitaram P, Kodali P, Silverman AL, Dmuchowski CF, Urdea M, Chan CS, Wilber JC: Levels of hepatitis $C$ virus RNA and liver histology in chronic type $C$ hepatitis. Am J Gastroenterol 89:1458-1461, 1994

5. Yuki N, Hayashi N, Takehara T, Hagiwara H, Hiramatsu N, Naito M, Kawanishi Y, Katayama K, Kasahara A, Fusamoto H, Kamada T: Serum hepatitis $C$ virus RNA levels and liver injury in volunteer blood donors. Am J Gastroenterol 89:1462-1466, 1994

6. Gretch D, Corey L, Wilson J, dela Rosa C, Wilson R, Carithers R Jr, Busch M, Hart J, Sayers M, Han J: Assessment of hepatitis $C$ virus RNA levels by quantitative competitive RNA polymerase chain reaction: High titer viremia correlates with advanced stage of disease. J Infect Dis 169:1219-1225, 1994

7. Shindo M, Arai K, Sokawa Y, Okuno T: The virological and histological states of anti-hepatitis $\mathrm{C}$ virus-positive subjects with normal liver biochemical values. Hepatology 22:418-425, 1995

8. Lau JYN, Davis GL, Kniffen J, Qian K, Urdea MS, Chan CS, Mizokami M, Neuwald PD, Wilber JC: Significance of serum hepatitis C virus RNA in chronic hepatitis C. Lancet 341:15011504,1993

9. Hagiwara $H$, Hayashi $N$. Mita E, Takehara T, Kasahara A, Fusamoto $H$, Kamada T: Quantitation analysis of hepatitis $C$ virus RNA in serum during interferon alfa therapy. Gastroenterology 104:877-883, 1993

10. Shindo M, Arai K, Sokawa Y, Okuno T: Hepatic hepatitis $C$ virus RNA as a predictor of a long-term response to interferon alfa therapy. Ann Intern Med 122:586-591, 1995

11. Brillanti S, Garson JA, Tuke PW: Effect of alpha-interferon therapy on hepatitis $C$ viremia in community acquired-chronic non- $A$, non-B hepatitis: $A$ quantitative polymerase chain reaction study. J Med Virol 34:136-141, 1991

12. Davis GL, Lau JYN, Urdea MS, Neuwald PD, Wilber JC, Lindsay K, Perrillo RP, Albrecht J: Quantitative detection of hepatitis $C$ virus RNA with a solid-phase signal amplification method: definition of optimal conditions for specimen collection and clinical application in interferon treated patients. Hepatology 19:1337-1341, 1994

13. Hino K, Okuda M, Konishi T, Ishiko H, Okita K: Serial assay of hepatitis $C$ virus RNA in serum for predicting response to interferon alfa therapy. Dig Dis Sci 40:14-20, 1995

14. Liang TJ, Rustgi V, Galun E, Blum HE: HCV RNA in patients 
with chronic hepatitis $C$ treated with interferon-alpha. J Med Virol 40:69-75, 1993

15. Magrin S, Craxi A, Fabiano C, Simoentti RG, Fiorentino G, Marino L, Diquattro O, Di Marco V, Loiacono O, Volpes $R$, Almasio P, Urdea MS, Neuwald P, Sacchez-Pescador R, Detmer J, Wilber JC, Paliaro L: Hepatitis C viremia in chronic liver disease: Relationship to interferon-alfa or corticosteroid treatment. Hepatology 19:273-279, 1994

16. Fong TL, Valinluck B, Govindarajan S, Charboneaau F, Adkins RH, Redeker AG: Short-term prednisone therapy affects hepatitis C virus RNA levels in chronic hepatitis C. Gastroenterology 107:196-199, 1994

17. Lau JYN, Davis GL, Brunson ME, Quian KP, Lin HJ, Quan S, DiNello R, Polito AJ, Scornik JC: Hepatitis C virus infection in kidney transplant recipients. Hepatology 18:1027-1031, 1993

18. Chazouilleres O, Kim M, Combs C. Ferrell L, Bacchetti P, Roberts J, Ascher NL, Neuwald P, Wilber J, Urdea M, Quan S, Sanchez-Pescador R, Wright TL: Quantitation of hepatitis C virus RNA in liver transplant recipients. Gastroenterology 106:994-996, 1994

19. Lefkowitch JH, Apfelbaum TF: Non-A, non-B hepatitis: Characterization of liver biopsy pathology. $\mathrm{J}$ Clin Gastroenterol 2:225-232, 1989

20. Mosnier JF, Degott C, Marcellin P, Henin D, Erlinger S, Benhamou JP: The intraportal lymphoid nodule and its environment in chronic active hepatitis $\mathrm{C}$ : An immunohistochemical study. Hepatology 17:366-371, 1993

21. Poralla T, Hutteroth TH, Meyer Zum Buschenfelde KH: Cellular cytotoxicity against autologous hepatocytes in acute and chronic non-A, non-B hepatitis. Gut 25:114-120, 1984

22. Mondelli $M$, Alberti A, Tremolada F, Williams R, Eddleston ALWF, Realdi G: In-vitro cell-mediated cytotoxicity for autologous liver cells in chronic non-A, non-B hepatitis. Clin Exp Immunol 63:147-155, 1986

23. Koziel MJ, Dudley D, Afdhal N, Choo QL, Houghton M, Ralston R, Walker BD: Hepatitis C virus (HCV)-specific cytotoxic $\mathrm{T}$ lymphocytes recognize epitopes in the core and envelope proteins of HCV. J Virol 67:7522-7532, 1993
24. Koziel MJ, Dudley D, Wong JT, Dienstag J, Houghton M, Ralston R, Walker BD: Intrahepatic cytotoxic $T$ lymphocytes specific for hepatitis $C$ virus in persons with chronic hepatitis. J Immunol 149:3339-3344, 1992

25. Kita H, Moriyama T, Kancko T, Harase I, Nomuta M, Miura H, Nakamura I, Yazaki Y, Imawari M: HLA B44-restricted cytotoxic $\mathrm{T}$ lymphocytes recognizing an epitope on hepatitis $\mathrm{C}$ virus nuclecapsid protein. Hepatology 18:1039-1044, 1993

26. Erickson AL, Houghton M, Choo QL, Weiner AJ, Ralston R, Muchmore E, Walker CM: Hepatitis C virus CTL responses in the liver of chimpanzees with acute and chronic hepatitis $C$. J Immunol 151:4189-4199, 1993

27. Imawari $M$, Nomura $M$, Kaieda $T$, Moriyama $T$, Oshimi $K$, Nakamura I, Gunji T, Ohnishi S. Ishikawa T, Nakagama $H$, Takaku F: Establishment of a human T-cell clone cytotoxic for both autologous and allogeneic hepatocytes from chronic hepatitis patients with type non-A, non-B virus. Proc Natl Acad Sci USA 86:2883-2887, 1989

28. Cheung RC, Chan RT, Lok ASF: Longitudinal study of hepatitis C viremia in chronic hepatitis C. J Med Virol 41:338-342, 1993

29. Lok ASF, Cheung RC, Liu V: Hepatitis $C$ viremia in patients with hepatitis $C$ virus infection. Hepatology 15:1007-1012, 1992

30. Widell A, Shev S, Mansson S, Zhang YY, Foberg U, Norkrans G, Weiland O, Kukus J, Nordenfeld E: Genotyping of hepatitis $C$ virus isolates by a modified polymerase chain reaction assay using type specific primers: epidemiologic applications. J Med Virol 44:272-279, 1994

31. Zhang YY, Lok ASF, Chan DTM, Widell A. A greater diversity of HCV genotypes found in Hong Kong than in mainland China. J Clin Micro (in press)

32. Farci P, Alter HJ, Wong D, Miller RH, Shih JW, Jett B, Purcell $\mathrm{RH}$ : A long-term study of hepatitis $C$ virus replication in non-A, non-B hepatitis. N Engl J Med 325:98-104, 1991

33. Garson JA, Turk PW, Makris M, Briggs M, Machin SJ, Preston FE, Tedder RS: Demonstration of viremia patterns in hemophiliacs treated with hepatitis $\mathrm{C}$ virus-contaminated factor VIII concentrates. Lancet 336:1022-1025, 1990 